\title{
On the Lexicographical Description of Equivalent Open Class Expressions*
}

\author{
Herbert Ernst Wiegand, Germanistisches Seminar, University of Heidelberg, \\ Heidelberg, Germany (herbert.ernst.wiegand@gs.uni-heidelberg.de)
}

\begin{abstract}
The contribution proceeds from the assumption that linguistic equivalence is already determined, and therefore only deals with questions of the lexicographical description of equivalent open class expressions in completely condensed dictionary articles in bilingual printed dictionaries, with the purpose of establishing a notion of lexicographical equivalence. Firstly, the most important differences between non-condensed, partially condensed and completely condensed dictionary articles are explained. In completely condensed dictionary articles, which are not natural language texts, addressing relationships are present. These relationships have a vital role in the lexicographical description of equivalent open class expressions. They are, therefore, explained in more detail. A further assumption for the development of a notion of lexicographical equivalence is the notion of semantic-pragmatic equivalence, which is therefore introduced briefly. Next, there is a stepwise development, by means of examples, of what one can understand by the notion of lexicographical equivalence. The developed notion of lexicographical equivalence can on the one hand form the point of departure for the lexicographical textualisation of semantic-pragmatic equivalence, and on the other hand it takes into consideration that the linguistic equivalence relationship has to be inferred first by the user-in-action by means of complex results of lexicographical textualisation. The developed notion of lexicographical equivalence presents a firm foundation for the optimisation of the presentation of lexicographical equivalence.
\end{abstract}

Keywords: ADDRESSING, SEMANTIC-PRAGMATIC EQUIVALENCE, LEXICOGRAPHICAL EQUIVALENCE, LEXICOGRAPHICAL TEXT CONDENSATION, CONDENSED DICTIONARY ARTICLES

Abstrakt: Zur lexikographischen Beschreibung nennlexikalischer äquivalenter Wortschatzeinheiten. Der Beitrag setzt voraus, dass die sprachliche Äquivalenz bereits ermittelt ist und behandelt entsprechend nur Fragen der lexikographischen Beschreibung äquivalenter nennlexikalischer Wortschatzeinheiten in vollständig kondensierten Wörterbuchartikeln zweisprachiger Printwörterbücher mit dem Ziel, einen Begriff von lexikographischer Äquivalenz zu etablieren. Zuerst werden die wichtigsten Unterschiede zwischen nichtkondensierten, partiell und vollständig kondensierten Wörterbuchartikeln erläutert. In vollständig kondensierten Wörterbuchartikeln, die keine natürlichsprachlichen Texte sind, treten Adressierungsbeziehungen auf. Diese spielen für die lexikographische Beschreibung äquivalenter Wortschatzeinheiten eine

* Translation of a German paper presented at a symposium on the occasion of the 65th birthday of Dieter Herberg, Mannheim, Germany, 25-26 October 2002. I thank Maria Smit for the translation. 
zentrale Rolle. Sie werden daher genauer erklärt. Eine weitere Voraussetzung für die Entwicklung eines Begriffs der lexikographischen Äquivalenz ist der Begriff der semantisch-pragmatischen Äquivalenz, der deshalb kurz eingeführt wird. Danach wird schrittweise an Beispielen entwickelt, was unter lexikographischer Äquivalenz zu verstehen ist. Der entwickelte Begriff der lexikographischen Äquivalenz kann einerseits den Ausgangspunkt bilden für die lexikographische Vertextung der semantisch-pragmatischen Äquivalenz, und andererseits berücksichtigt er, dass die sprachlichen Äquivalenzbeziehungen vom Benutzer-in-actu anhand der komplexen Ergebnisse der lexikographischen Vertextung erst erschlossen werden müssen. Der entwickelte Begriff der lexikographischen Äquivalenz bietet eine stabile Grundlage für die Optimierung der lexikographischen Äquivalentpräsentation.

Schlagworte: ADRESSIERUNG, SEMANTISCH-PRAGMATISCHE ÄQUIVALENZ, LEXIKOGRAPHISCHE ÄQUIVALENZ, LEXIKOGRAPHISCHE TEXTVERDICHTUNG, KONDENSIERTER WÖRTERBUCHARTIKEL

\section{Some assumptions from lexicographical theory}

Firstly, some assumptions from lexicographical theory, which have been developed in more recent works (cf. Wiegand 2002, 2002a, 2002b, 2002c and 2003) and which are necessary in order to understand the following expositions, are briefly explained or at least referred to. This article does not deal with genuine linguistic aspects of equivalence. On the contrary, it is taken for granted that the equivalence of the open class expressions is already determined linguistically, so that - according to the title of the article - specific questions of the lexicographical description of equivalent open class expressions (and here the topic is being narrowed) in completely condensed dictionary articles in bilingual printed dictionaries are dealt with. Therefore, some explanations will be given of the type of completely condensed dictionary articles and of the textual features of articles of this article type, preferred in modern bilingual lexicography.

Fig. 1-1 shows two non-condensed dictionary articles (wa); wa $a_{1}$ and $w_{2}$ are only of interest in view of the present context because they contain lexicographical texts in natural language which exhibit completely well-marked sentence and textual syntactic structures in accordance with the syntax of a specific natural language, so that they can as such be read continuously, in the same way as other natural language texts for which only linguistic competence and not any specific competence for dictionary use is needed.

$w_{1}$ : Plutokratie

Zu den beliebten Diffamierungen demokratischer Staatsformen, insbesondere der angelsächsischen Demokratien durch die NS-Propaganda, zählte der Begriff Plutokratie als »Herrschaft der Reichen«. $\mathrm{wa}_{2}$ : Action

gehört zu den Lieblingsvokabeln der Jungendszene und ist zugleich Inbegriff eines erfüllten Daseins. Interessant ist es in erster Linie da, wo voll Action ist oder wo man Action machen kann - da ist eben auch Leben. Das Wort steht für eine Betriebsamkeit, die vor allem durch Spontaneität und Kreativität gekennzeichnet ist.

Fig. 1-1: Non-condensed dictionary articles $w_{1} a_{1}$ and $w_{2}$ from Schlosser 2000 and Müller-Thurau 1983 
Articles $\mathrm{wa}_{1}$ and $\mathrm{wa}_{2}$ do not exhibit any items, microstructures or addressing structures. These articles contain item texts. Item texts, which do not always have to be complete dictionary articles, contain at least one complete sentence (cf. Wiegand 2000d and 2003); one should note here that item texts are lexicographical texts containing language-reflexive descriptions on a meta-level of the subject of the particular dictionary domain (in the sense of Wiegand 1998: 302) (in the second way of using the language treated in the dictionary, in the sense of Wiegand 1983: 416). That means that vouched example items which mention a sentence or more than one sentence, as in "Die Glocke ruft [...] entrückt" in dictionary article wa $\mathrm{w}_{3}$ in Fig. 1-2 are not item texts.

wa $_{3}$

\section{Blutstuhl}

Stuhl für einen Hinzurichtenden

Die Glocke ruft, das Stäbchen bricht. / Wie

sie mich binden und packen! / Zum

Blutstuhl bin ich schon entrückt.

Faust I / Kerker / Vers 4590 ff.

HA 3, 144

Fig. 1-2: Completely condensed dictionary article was from Müller 1999

Completely condensed dictionary articles do not exhibit item texts. The bilingual articles $w_{4}$ and wa $\mathrm{w}_{5}$ in Fig. 1-3 are also completely condensed dictionary articles. They can be clearly distinguished from $\mathrm{wa}_{3}$, because they do not exhibit a micro-architecture and accordingly also no architectonically phased-out microstructures. Therefore $\mathrm{wa}_{4}$ and $\mathrm{wa}_{5}$ are compressed to a greater extent than $\mathrm{wa}_{3}$, which considerably complicates the perception of the text form. ${ }^{1}$

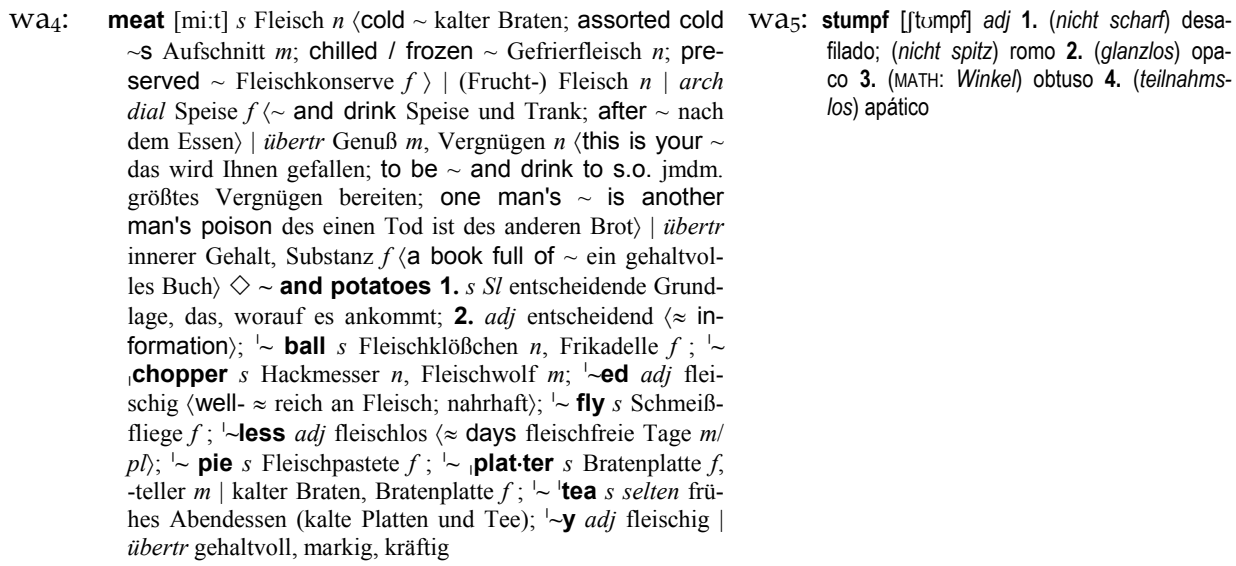

Fig. 1-3: Completely condensed dictionary articles wa $a_{4}$ and wa $a_{5}$ from Neubert and Gröger 1991 and from DE. Dt.-Span./Es.-Al. 1999.

Partially condensed dictionary articles exhibit, apart from items, at least one 
item text and thus microstructures which are heterogeneous with regard to their elements (in the sense of Wiegand 2003). An example is wa ${ }_{6}$ in Fig. 1-4. The item text appears between the asterisk and the double asterisk.

wa $\quad$ Parteidisziplin, die / Schon vor 1933 / : Die für jedes Mitglied stets verbindliche Pflicht, alle Parteibeschlüsse $\mathrm{zu}$ befolgen. * Die P. ist eine der wesentlichen Normen für alle Mitglieder und $\rightarrow$ Kandidaten der Partei. Die Einhaltung der P. wird von der $\rightarrow$ Parteikontrollkommission überwacht, Verletzungen der $P$. werden mit $\rightarrow$ Parteistrafen belegt. ** Kein Plural.

Fig. 1-4: Partially condensed dictionary article $\mathrm{wa}_{6}$ from Kinne and Strube-Edelmann 1980

After the exemplified explanations by means of $\mathrm{wa}_{1}$ to $\mathrm{wa}_{6}$, it is possible to determine the typological location of completely condensed dictionary articles in a typological system which has in the meantime been drawn up as shown in Fig. 1-5 (cf. Wiegand 2002d: 510 and 2003).

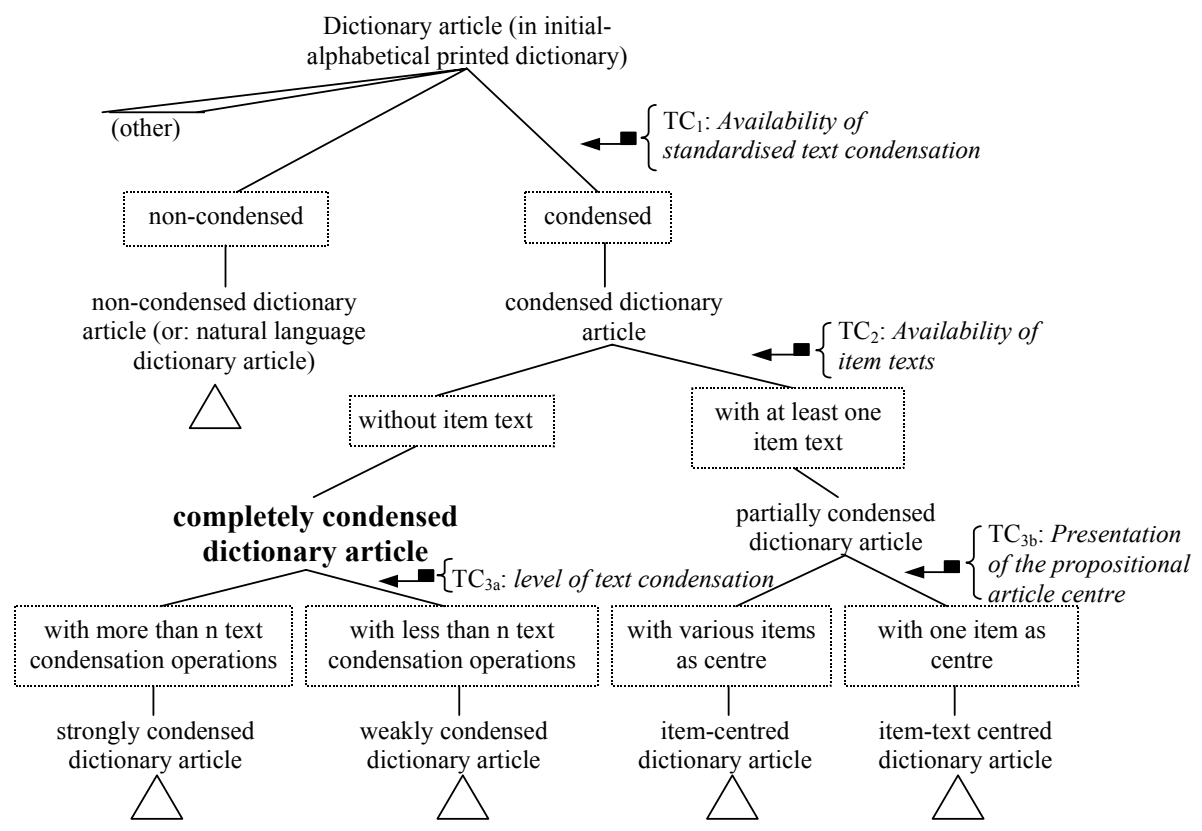

Fig. 1-5: Excerpt from a typological system for dictionary articles in initial-alphabetical printed dictionaries; Abbreviations and notation conventions: TC = typology criterion; " means the application of TC leads to the subdivision 
As opposed to non-condensed dictionary articles, completely condensed dictionary articles such as $\mathrm{wa}_{3}, \mathrm{wa}_{4}$ and $\mathrm{wa}_{5}$ are not natural language texts, because they do not exhibit natural language syntax. The syntactical relationships and therefore the cohesion-forming phenomena are omitted in the process of inner text condensation (in the sense of Wiegand 1998: 13ff and 2002: 126ff). They are replaced by the article-internal addressing relationships which contain items indicating their reference addresses. The non-natural article syntax of a completely condensed dictionary article is not only recognizable on the basis of linguistic competence; competence in the use of dictionaries is also necessary. When designing dictionary articles, one should always proceed from the assumption that a user may not be in a position to relate the text constituents of a dictionary article to each other on the basis of semantic features of the lexicographically treated linguistic expressions. It should rather be obvious to a competent user (in the sense of Wiegand 1998: 506) to which reference addresses an item is addressed by means of the features of the article form. If that is not the case, the textual prerequisites ensuring that a user-in-action can infer lexicographical information by means of the article texts and thereby systematically obtain lacking knowledge, are not provided. For it is necessary for successful information retrieval in the process of user actions that the user-in-action, who does not know the dictionary subject sufficiently, can link the items on the basis of features of the article form to their reference addresses.

The article-internal addressing also plays a vital role in the lexicographical description of equivalent open class expressions. Therefore, some more introductory explanations will be given by means of wa 7 in Fig. 1-6, which especially should help one not to confuse the addressing relationship with other relationships or, as recently happened in Engelberg and Lemnitzer (2001: 137ff; compare with Wiegand 2002), misunderstand it.

wa7: bed [bed] 1. $s$ Bett $n\langle\sim$ and board Jur Bett $n$ u. Tisch $m$; and breakfast Übernachtung $f$ mit Frühstück; double Doppelbett $n$; single $\sim$ Einzelbett $n$, Übernachtung $f$ für eine Person; to be brought to $\sim$ of niederkommen mit; to go to $\sim$ ins Bett gehen; to keep / take to one's $\sim$ das Bett hüten, im Bett bleiben müssen; to make the $\sim$ das Bett machen; of roses leichtes od unbeschwertes Leben; of thorns Schmerzenslager $n\rangle \mid$ Bett $n$, Matratze $f$ feather Unterbett $n\rangle \mid$ (Tier) Lager $n \mid$ Lager $n$ (aus Stroh u. ä.) | (Fluß-) Bett $n \mid$ Tech Unterlage $f$, Bettung $f$, Fundament $n \mid$ Eisenb Unterbau $m$, Schotterbett $n \mid$ Arch Untermauerung $f \mid$ Geol Lager $n$, Schicht $f \mid$ Bergb Flöz $n \mid$ (Blumen-) Beet $n$; 2. (' $\sim$ ded, ' $\sim$ ded) $v t$ (jmdn.) ins Bett legen, zu Bett bringen $\mid$ betten (auch übertr) | Tech betten, einlegen, einmörteln, festlegen (in in); down (Pferd) in der Stall bringen, mit Streu versorgen | Gartenb (Blumen u. ä.) einpflanzen, in Beete pflanzen; out Gartenb (Pflanzen) auspflanzen; vi auch $\sim$ down sich schlafen legen, sich niederlegen $\mid \mathrm{zu}-$ sammen schlafen (with mit) | (Tier) lagern

Fig. 1-6: Completely condensed dictionary article wa from Neubert and Gröger 1991 
The following explanations are illustrated by means of wa7 in Fig 1-7. In wa7, the target language item giving the word equivalent (ÄA.W) "Bett" is addressed to the item giving the form of the lemma sign (LZGA) "bed"2; it is a case of non-adjacent left addressing that is three times expanded. The textual distance from an item to its reference address has the value 3 , because three elementary items are placed between the reference address "bed" and the addressed item "Bett", namely: the item giving the pronunciation (AusA) "bed", the item giving the word class distinction (WUntA) "1." and the item giving the word class (WAA) "s" (cf. Wiegand 2002: 144ff). The addressing relationship (cf. (1) in Fig. 1-7) should not be confused with the item relationship (cf. (4) in Fig. 1-7). For the item giving the word equivalent "Bett" is not by chance an item for another item, namely for the item giving the form of the lemma sign "bed", it is rather an item to the lemma sign bed, which is mentioned with "bed". The item giving the form of the lemma sign belongs to the items giving the form(s), with which something else is thus given, namely that at least one linguistic form is mentioned (cf. the relationship of mentioning (3) in Fig. 1-7). The converse addressing relationship is called reference addressing relationship (cf. (2) in Fig. 17); "bed" is the non-adjacent left-situated reference address for "Bett". The converse item relationship is the treatment relationship (cf. (5) in Fig. 1-7); the lemma sign bed is treated lexicographically by means of the item giving the word equivalent "Bett", so that the 2-tuple (bed, Bett) forms a bilingual lexicographical treatment unit.

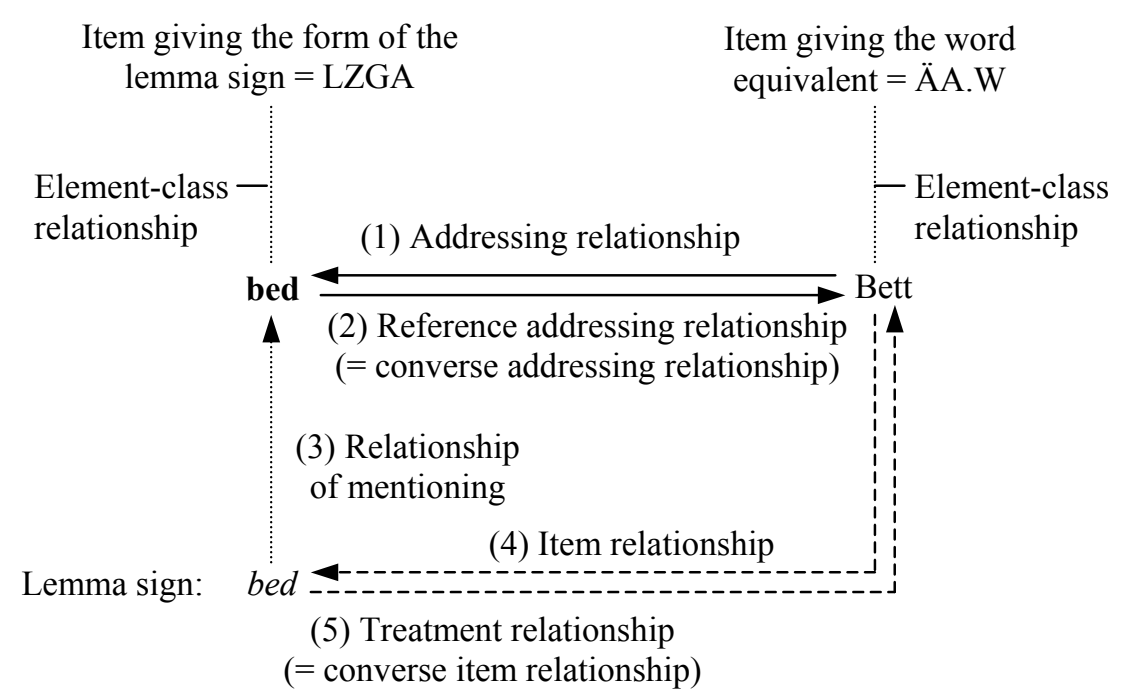

Fig. 1-7: Illustration of textual relationships in dictionary articles according to wa7; Notation conventions: " $\mathrm{y}$ ……...... $\mathrm{Y}$ " means $\mathrm{y}$ is an element of $\mathrm{Y}(=\mathrm{y} \in \mathrm{Y}) ; \mathrm{y} \longrightarrow \mathrm{x}$ " means $\mathrm{y}$ is the reference address for $x$; " $\mathrm{x} \longrightarrow \mathrm{y}$ " means $x$ is addressed to $y ; " \mathrm{u} \cdots . . . . . . \mathrm{y}$ " means $u$ is mentioned by $y$; " $\mathrm{x}-\mathrm{u}$ " means $x$ is an item for $u$; "u---- $\rightarrow$ " means $u$ is treated lexicographically by means of $x$ 
The following abbreviations should now be introduced:

- $\mathrm{RT}=$ two-place relation term

- $\quad \mathrm{R}_{\mathrm{Ad}}=$ addressing relation

- $\quad \mathrm{R}_{\mathrm{BeAd}}=$ reference addressing relation

- $\quad \mathrm{R}_{\mathrm{Erw}}=$ relation of mentioning

- $\mathrm{R}_{\mathrm{An}}=$ item relation

- $\mathrm{R}_{\text {Bea }}=$ treatment relation

Then the following propositions, ordered into five groups, are valid:

(1) $\quad \mathrm{RT}_{1}(\mathrm{x}, \mathrm{y})=\mathrm{x}$ is addressed to $\mathrm{y} ; \mathrm{R}_{\mathrm{Ad}}\left(\mathrm{wa}_{7}\right)=\left\{(\mathrm{x}, \mathrm{y}) \mid \mathrm{RT}_{1}(\mathrm{x}, \mathrm{y})\right\}_{\mathrm{wa}_{7}} ;$

"Bett" is addressed to "bed"; (Bett, bed $) \in \mathrm{R}_{\mathrm{Ad}}\left(\mathrm{wa}_{7}\right)$.

(2) $\operatorname{RT}_{2}(y, x)=y$ is the reference address for $x ; R_{\text {BeAd }}\left(w_{7}\right)=$ $\left\{(y, x) \mid R_{2}(y, x)\right\}_{w_{7}} ; "$ "bed" is the reference address for "Bett"; (bed, Bett) $\in \mathrm{R}_{\mathrm{BeAd}}\left(\mathrm{wa}_{7}\right)$.

(3) $\mathrm{RT}_{3}(\mathrm{u}, \mathrm{y})=\mathrm{u}$ is mentioned with the item giving the form; $\mathrm{R}_{\mathrm{Erw}}\left(\mathrm{wa}_{7}\right)=\left\{(\mathrm{u}, \mathrm{y}) \mid \mathrm{RT}_{3}(\mathrm{u}, \mathrm{y})\right\}_{\mathrm{wa}_{7}} ;$ "bed" is mentioned with the item giving the form "bed"; (bed, bed) $\in \mathrm{R}_{\mathrm{Erw}}\left(\mathrm{wa}_{7}\right)$.

(4) $\quad \mathrm{RT}_{4}(\mathrm{x}, \mathrm{u})=\mathrm{x}$ is an item for $\mathrm{u} ; \mathrm{R}_{\mathrm{An}}\left(\mathrm{wa}_{7}\right)=\left\{(\mathrm{x}, \mathrm{u}) \mid \mathrm{RT}_{4}(\mathrm{x}, \mathrm{u})\right\}_{\mathrm{wa}_{7}}$;

"Bett" is an item for "bed"; (Bett, bed $) \in \mathrm{R}_{\mathrm{An}}\left(\mathrm{wa}_{7}\right)$.

(5) $\quad \mathrm{RT}_{5}(\mathrm{u}, \mathrm{x})=\mathrm{u}$ is treated by means of the item $\mathrm{x} ; \mathrm{R}_{\text {Bea }}\left(\mathrm{wa}_{7}\right)=$

$\left\{(\mathrm{u}, \mathrm{x}) \mid \mathrm{RT}_{5}(\mathrm{u}, \mathrm{x})\right\} ;$; bed" is treated by means of the item

"Bett"; (bed, Bett) $\in \mathrm{R}_{\text {Bea }}\left(\mathrm{wa}_{7}\right)$.

Finally, the lexicographical-theoretical assumptions include the notion of semantic-pragmatic equivalence for open class expressions which has been developed in recent works (cf. Wiegand 2002a, 2002b and 2002c). The following brief remarks should be given about this notion: In interlingual equivalence relations, one finds lexical-semantic units; these are those abstract units which Alan Cruse called lexical units (cf. Cruse 1987: 76f). They consist of an abstract lexical form, according to which all concrete forms of an accompanying inflection paradigm can be realised, and also of an accompanying meaning (in the sense of one "sememe"). Accordingly, a lexeme is a family of lexical-semantic units (cf. Wiegand 2002b: Fig. 2-3). When lexical-semantic units are referred to below, italic capital letters are used (which can be numbered with subscripts). If a form realised according to a lexical-semantic unit of a language A (e.g. English bed is a realisation of $\left.B E D_{1}\right)$ is valid as a semantic-pragmatic equivalent to a form realised according to a lexical-semantic unit of a language $B$ (e.g. German Bett realises to $B E T T_{1}$ ), they should be in two four-place equivalence relations to which one belongs to the type of lexical-semantic (ls) equivalence relation and the other to the type of lexical-pragmatic (lp) equivalence relation, so that the first-mentioned relation is determined by the relation term 
$\mathrm{RT}_{\mathrm{ls}}(\mathrm{x}, \mathrm{y}, \mathrm{z}, \mathrm{k})=$ " $\mathrm{x}$ is a lexical-semantic equivalent for $\mathrm{y}$ with reference to $\mathrm{z}$ relating to the co-text class $\mathrm{k}$ ", and the latter relation is determined by the relation term $\operatorname{RT}_{\mathrm{lp}}(\mathrm{x}, \mathrm{y}, \mathrm{u}, \mathrm{k})=$ " $\mathrm{x}$ is a lexical-pragmatic equivalent to $\mathrm{y}$ with reference to $\mathrm{u}$ relating to the co-text class $k$ ". The variables " $\mathrm{x"}$ and " $\mathrm{y}$ " can be inserted with lexical-semantic units; "z" in $\mathrm{RT}_{\mathrm{ls}}(\mathrm{x}, \mathrm{y}, \mathrm{z}, \mathrm{k})$ and " $\mathrm{u}$ " in $\mathrm{RT}_{\mathrm{lp}}(\mathrm{x}, \mathrm{y}, \mathrm{u}, \mathrm{k})$ are provided for the equivalence criteria: For " $\mathrm{z}$ " one can insert markers for reference objects and for "u" one can insert pragmatic labels. The variable " $\mathrm{k}$ " is provided for the co-textual equivalence stipulation. With wa 7 as a lexicographical reference text, one can now make the following statements (claiming truth-value):

(i) $B E D_{1}$ is lexically-semantically equivalent to $B E T T_{1}$ with reference to "Bett" relating to standard-language habitual usage of all accompanying forms.

(ii) $B E D_{1}$ is lexically-pragmatically equivalent to $B E T T_{1}$ with reference to the pragmatic zero marking relating to standard-language habitual usage of all accompanying forms. ${ }^{3}$

If (i) and (ii) are valid, then $B E D_{1}$ (and therefore bed and beds) and $B E T T_{1}$ (and therefore Bett, Bett(e)s, Betten) are semantically-pragmatically equivalent, so that a case of word-word equivalence (short: word equivalence) and therefore a case of lexical-internal (or lexicon-specific) equivalence is effected. These explanations should be sufficient for now (cf. further in Wiegand 2002b).

\section{On the notion of lexicographical equivalence}

In the following section, I want to give an impression of what a concept of lexicographical equivalence that represents one of the assumptions for an appropriate description of equivalent open class expressions in bilingual printed dictionaries should look like. Such a concept should be understood in such a way that it can, on the one hand, provide lexicographers with a starting point for lexicographical textualisation of semantic-pragmatic equivalence in completely condensed dictionary articles, and, on the other hand, take into account that the linguistic equivalence relationship should be inferred by the user-in-action by means of the absolutely complex lexicographical textualisation outcomes in condensed texts.

The reason for constructing a concept of the described kind lies in the following facts: Dictionary research not only deals with linguistic equivalents, but also deals with the fact that linguistic equivalence must be, among others things, presented in a completely condensed dictionary article and commented on by means of further items. Equivalents should always be mentioned by means of items giving the equivalent; items giving the equivalent are therefore - just like other items - microstructural text constituents - text segments with a specific item form, at least one specific genuine item purpose and one specific item position; because equivalents which are mentioned should also be 
commented on, the items giving the equivalent, function as article-internal reference addresses for other equivalence-relevant items and are themselves article-internally addressed to other equivalence-relevant items, with the result that the particular semantic-pragmatic equivalence (which is conveyed lexicologically and textualised lexicographically) has to be inferred as a specific element of knowledge by the user-in-action first by means of textual facts of a condensed dictionary article in the process of user actions (which are not only reading actions based on linguistic competence).

Next we illustrate graphically the following exerpt (e) from wa7:

$$
\mathrm{e}_{1}: \text { bed }[\ldots] \text { Bett }[\ldots]
$$

In $\mathrm{e}_{1}$, a semantic-pragmatic word-word equivalence (short: word equivalence) is textualised lexicographically. The competent user who wants to understand this textualisation completely, does not only have to know that "Bett" is addressed to "bed"; he/she also, according to the accompanying metatext in Neubert and Gröger 1991, has to know that a zero item should be taken into account, since there are no items in $\mathrm{e}_{1}$ in the positions provided for pragmatic labels. This means: bed and Bett are pragmatically non-marked (in all the dimensions of marking which the dictionary takes into account). Therefore, one should take into account two blank items $\left({ }_{i} \mathrm{AB}_{\mathrm{j}}\right)$. A corresponding representation, in which the positional neighbouring variables "i" and "j" are filled, so that both the blank items are distinguished, then has the following form:

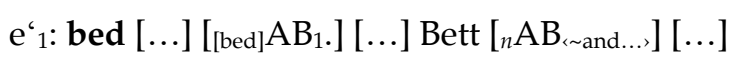

The item giving the pragmatic zero marking (A-pragNM) that is named with "[[bed] $\left.A B_{1}.\right] "$ is source language-internally addressed to "bed"; the item giving the pragmatic zero marking that is named with " $\left[{ }_{n} \mathrm{AB}_{\text {( and... }}\right]$ " is target language-internally addressed to the item giving the equivalent, "Bett". In both cases, left addressing occurs. However, in the domain of the two-place relation of the type of lexicographical equivalence relations which belong to $e_{1}-$ it is called $R_{\operatorname{lex} \ddot{A}}\left(\mathrm{e}_{1}\right)$ - appears a set $\left\{\left(\mathbf{b e d},\left[\right.\right.\right.$ [bed] $\left.\left.\left.\mathrm{AB}_{1}.\right]\right)\right\}$, of which the item pair (bed, [ [bed] $\left.\left.A B_{1}.\right]\right)$ is an element ${ }^{4}$; as can easily be seen, this pair is an element of the reference addressing relation $R_{\text {BeAd }}\left(w a_{7}\right)$ (cf. (2) above, so that (bed, [ [bed] $\left.A B_{1}.\right]$ ) $\in R_{\text {BeAd }}$ is valid. In the range of $R_{\operatorname{lex} \ddot{A}}\left(e_{1}\right)$ also appears a set with an element of $\mathrm{R}_{\mathrm{BeAd}}(\mathrm{wa} 7)$, namely the element: (Bett, $\left.{ }_{n} \mathrm{AB}_{\ltimes \sim \text { and... }}\right]$ ); accordingly, (Bett, $\left.\left[{ }_{n} A B_{\text {i and.... }}\right]\right) \in \mathrm{R}_{\mathrm{BeAd}}$ is valid. The lexicological fact that $B E D_{1}$ and $B E T T_{1}$ are semantically-pragmatically equivalent and therefore that $B E D_{1}$ and $B E T T_{1}$ stand in two four-place relations, namely in a type of lexical-semantic equivalence and a type of lexical-pragmatic equivalence, is thus textualised lexicographically in such a way that a two-place relation of the type of lexicographical equivalence relation is given. In Fig. 2-1, this fact which has just been explained according to Wiegand (2002b), is illustrated graphically. 


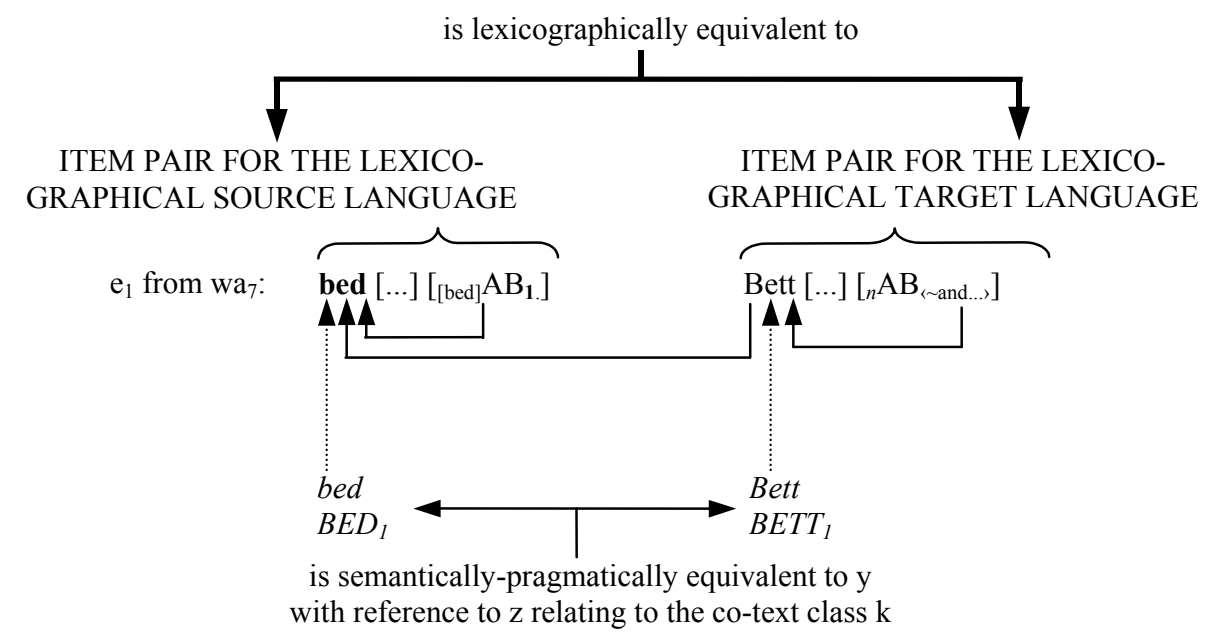

Fig. 2-1: Illustration of a lexicographical equivalence relation which is specific for open class expressions and based on semantic-pragmatic word equivalence; Abbre-

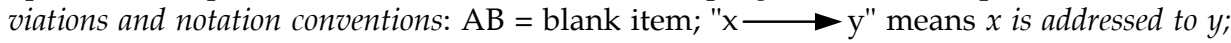
$\mathrm{u} \mathrm{u} \cdots \cdots \cdots \cdots \cdot \mathrm{z}$ " means $u$ is mentioned by $z$.

Now the following statement is valid:

(bed, [[bed] $\left.\left.\mathrm{AB}_{1}.\right]\right)$ is lexicographically equivalent to (Bett, $\left.\left[{ }_{n} \mathrm{AB}_{\sim \sim a n d . . .]}\right]\right)$.

Accordingly, the following is also valid:

$$
\mathrm{R}_{\text {lexÄ}}\left(\mathrm{e}_{1}\right)=\left\{\left\langle\left\{\text { bed, }\left[\text { [bed] } \mathrm{AB}_{1} \cdot\right]\right)\right\},\left\{\left(\text { Bett, }\left[{ }_{n} \mathrm{AB}_{\text {( andd ... }}\right)\right\}\right\rangle\right\} .
$$

The appropriate reference texts for the analysis of lexicographical equivalence relations are bilingual dictionary articles. Accordingly, $R_{\text {lex } \ddot{A}}\left(e_{1}\right)$ is only a partial relation (of the cardinality 1) of the lexicographical equivalence relation

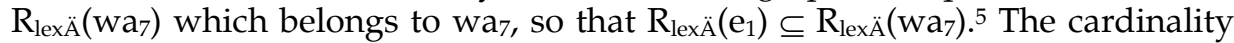
of an article-specific lexicographical equivalence relation $R_{\text {lex }}\left(w a_{x}\right)$ has precisely the same numerical value as the number of equivalence relations which are lexicographically treated in wax and thus has the same numerical value as the number of target language items giving the equivalent in wax; or, put differently: $R_{\text {lexÄ}}\left(w a_{x}\right)$ is equipotent to that subset of $R_{B e A d}\left(w a_{x}\right)$ of which the elements only exhibit equivalence-relevant items as components. As one can easily count in Fig 1-3, the cardinality of $R_{\operatorname{lex}}\left(w a_{5}\right)$ is, for example, 5, because wa exhibits the following five items giving the equivalent: desafilado, romo, opaco, obtuso, and apático.

In order to make the formal connections and the connections of contents even more comprehensible, let us look at another simple example below. We isolate the following part $(\mathrm{T})$ from $(\mathrm{v}) \mathrm{wa}_{4}$ :

Tvwa4: meat [mi:t] s Fleisch $n$ 〈cold $\sim$ kalter Braten; assorted [...]〉 [...] 
In Tvwa 4 , two relationships of the semantic-pragmatic equivalence which are specific for open class expressions are textualised lexicographically: one of word equivalence and one of equivalence of syntagmas. The result of the textualisation for word equivalence can be presented as follows, taking into account the zero items for which the blank items are presented:

$\mathrm{e}_{2}:$ Tv Tvwa 4 : meat $[\ldots]\left[\left[\mathrm{min}_{\mathrm{t}}\right] \mathrm{AB}_{s}\right][\ldots]$ Fleisch $\left[{ }_{n} \mathrm{AB}_{\text {cold } \ldots . .}\right][\ldots]$

For the equivalence of syntagmas, there is the following form:

$\mathrm{e}_{3}$ Tv Tvwa4: cold $\sim$ [cold $\left.\sim \mathrm{AB}_{\text {kalter }}\right]$ kalter Braten [Braten $\mathrm{AB}_{\text {ass...] }}[\ldots]$

An illustration of $e_{3}$ can be found in Fig. 2-2.

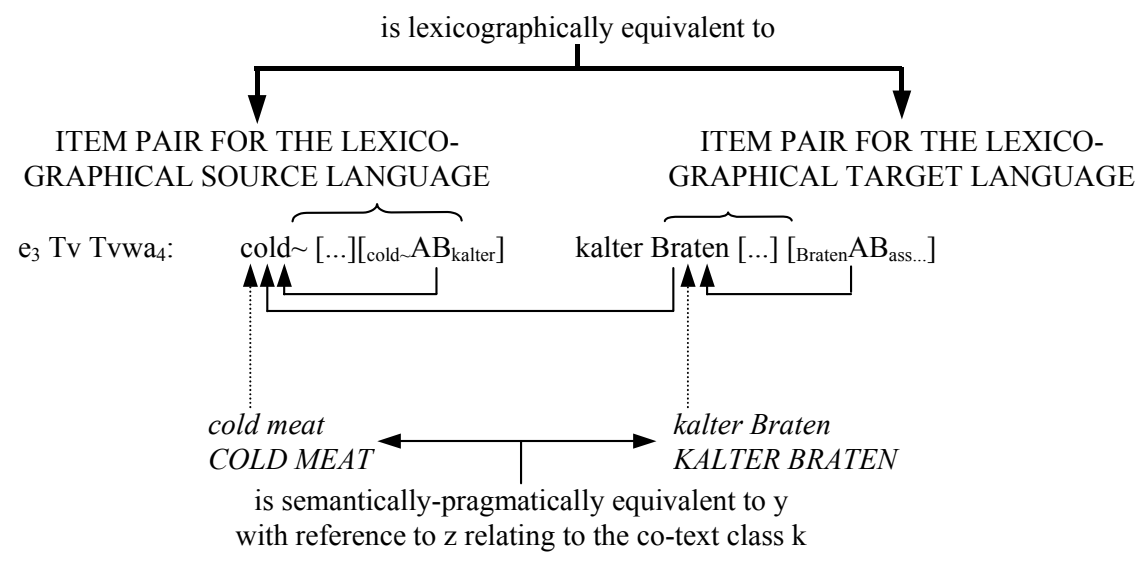

Fig. 2-2: Illustration of a lexicographical equivalence relation which is specific for open class expressions and based on semantic-pragmatic equivalence of syntagmas; Notation conventions: as in Fig. 2-1.

Next, we construct a relation of the type of lexicographical equivalence relations which belongs to $\mathrm{Tvwa}_{4}$ and which is determined by the proposition schema $\operatorname{AF}_{\text {lex } \ddot{A}}\left(\operatorname{Tvwa}_{4}\right)=$ " $x$ is lexicographically equivalent to $y "$; this relation is called $R_{\text {lex }}\left(T_{v w a}\right)$. Firstly, we constitute the base set for the variable " $x "$ in $\mathrm{AF}_{\text {lex } \ddot{A}}\left(\mathrm{Tvwa}_{4}\right)$ - this is $\mathrm{A}\left(\mathrm{Tvwa}_{4}\right)$ - and then the base set $\mathrm{B}\left(\mathrm{Tvwa}_{4}\right)$ for the variable " $y$ ". For the source language range of the variables " $x "$ are then needed the following equivalence-relevant items, which are named here with their item classes and accompanying class symbols:

- $\quad$ meat $\in$ LZGA (item giving the form of the lemma sign)

- $\quad\left[\right.$ [mi:t] $\left.\mathrm{AB}_{s}\right] \in \mathrm{A}$-pragNM (item giving the pragmatic zero marking [in the item position between "[mi:t]" and "s"])

- $\quad$ cold $\sim \in$ v.KollA (condensed item giving the collocation) 
- $\quad\left[\right.$ cold $\left.\sim \mathrm{AB}_{\text {kalter}}\right] \in \mathrm{A}$-pragNM (item giving the pragmatic zero marking [in the item position between "cold " and "kalter Braten"]).

For the target language range of the variables of "y", the following four equivalence-relevant items come to the fore from the reference text Tvwa

- Fleisch $\in$ ÄA.W (item giving the word equivalent)

- $\quad\left[{ }_{n} \mathrm{AB}_{\text {ccold.... }}\right] \in \mathrm{A}$-pragNM (item giving the pragmatic zero marking [in the item position between " $n$ " and "cold "])

- $\quad$ kalter Braten $\in$ ÄA.Synt (item giving the syntagmatic equivalent)

- $\quad\left[\right.$ Braten $\left.A B_{\text {ass... }}\right] \in A$-pragNM (item giving the pragmatic zero marking [in the item position between "kalter Braten" and "assorted cold $\sim \mathrm{s} "])$.

With the eight above-mentioned items we now have all the first components $\left(\mathrm{k}_{1}\right)$ and all second components $\left(\mathrm{k}_{2}\right)$ of the 2-tuple, which appear as elements of those sets which are elements of $\mathrm{A}\left(\mathrm{Tvwa}_{4}\right)$ and $\mathrm{B}\left(\mathrm{Tvwa}_{4}\right)$, so that both these base sets for $\mathrm{AF}_{\text {lexÄ }}\left(\mathrm{Tvwa}_{4}\right)$ can be presented as follows:

$$
\begin{aligned}
& \mathrm{A}\left(\text { Tvwa }_{4}\right)=\left\{\left\{\left(\text { meat },\left[\left[\text { mi:tt } \mathrm{AB}_{s}\right]\right)\right\},\left\{\left(\text { cold } \sim,\left[\text { cold } \sim \mathrm{AB}_{\text {kalter }}\right]\right)\right\}\right\} .\right. \\
& \left.\mathrm{B}\left(\text { Tvwa }_{4}\right)=\left\{\left(\text { Fleisch, }\left[{ }_{n} \mathrm{AB}_{\text {cold } \ldots . .}\right]\right)\right\},\left\{\left(\text { kalter Braten, }\left[\text { Braten } \mathrm{AB}_{\text {ass } \ldots]}\right]\right)\right\}\right\} .
\end{aligned}
$$

Next, we construct the Cartesian product of $\mathrm{A}\left(\mathrm{Tvwa}_{4}\right)$ and $\mathrm{B}\left(\mathrm{Tvwa}_{4}\right)$, thus:

$$
\mathrm{A}\left(\mathrm{Tvwa}_{4}\right) \times \mathrm{B}\left(\text { Tvwa }_{4}\right)=\left\{\left(\mathrm{k}_{1}, \mathrm{k}_{2}\right) \mid \mathrm{k}_{1} \in \mathrm{A}\left(\mathrm{Tvwa}_{4}\right) \wedge \mathrm{k}_{2} \in \mathrm{B}\left(\operatorname{Tvwa}_{4}\right)\right\} .
$$

Accordingly, the following set of four elements is found:

$$
\begin{aligned}
& \mathrm{A}\left(\mathrm{Tvwa}_{4}\right) \times \mathrm{B}\left(\mathrm{Tvwa}_{4}\right)=\left\{<\left\{\left(\text { meat, }\left[\text { mi:t. } \mathrm{AB}_{s}\right]\right)\right\},\right. \\
& \left.\left\{\left(\text { Fleisch, }\left[{ }_{n} \mathrm{AB}_{\text {<cold... }}\right]\right)\right\}\right\rangle,\left\langle\left\{\left(\text { meat, }\left[{ }_{\text {mi:t }]} \mathrm{AB}_{s}\right]\right)\right\}\right. \text {, } \\
& \left.\left.\left\{\left(\text { kalter Braten, [Braten } A B_{\text {ass... }}\right)\right\}\right\},\left\{\left(\text { cold } \sim, \text { [cold } \sim \mathrm{AB}_{\text {kalter }}\right]\right)\right\} \text {, } \\
& \left\{\left(\text { Fleisch, }\left[{ }_{n} A B_{\text {cold... }}\right]\right)\right\rangle,\left\langle\left\{\left(\text { cold } \sim \text {, [cold } \sim A B_{\text {kalter }}\right]\right)\right\} \text {, } \\
& \left.\left\{\left(\text { kalter Braten, [Braten } \mathrm{AB}_{\text {ass...] }}\right)\right\}>\right\} \text {. }
\end{aligned}
$$

Next, we select from the set $\mathrm{A}\left(\mathrm{Tvwa}_{4}\right) \times \mathrm{B}\left(\mathrm{Tvwa}_{4}\right)$ all the elements which exhibit a true proposition schema when the components of their 2-tuple are substituted in the proposition schema "x is lexicographically equivalent to $y "$ ", in this case $k_{1}$ for " $x$ " and the component $k_{2}$ for " $y$ ". Then we get the subset of $\mathrm{A}\left(\mathrm{Tvwa}_{4}\right) \times \mathrm{B}\left(\mathrm{Tvwa}_{4}\right)$. This set is the lexicographical equivalence relation $\mathrm{R}_{\text {lex }}\left(\mathrm{Tvwa}_{4}\right)$ to the completely condensed lexicographical reference text $\mathrm{Tvwa}_{4}$, so that the following is valid: $R_{\operatorname{lex} \ddot{A}}\left(\operatorname{Tvwa}_{4}\right) \subseteq \mathrm{A}\left(\mathrm{Tvwa}_{4}\right) \times \mathrm{B}\left(\mathrm{Tvwa}_{4}\right)$.

$R_{\operatorname{lex} \ddot{A}}\left(\operatorname{Tvwa}_{4}\right)$ is a subset of $R_{\operatorname{lex} \ddot{A}}\left(w a_{4}\right)$, exhibits the cardinality 2 and can be presented (extensionally complete) as follows:

$$
\begin{aligned}
& \mathrm{R}_{\text {lex } \ddot{A}}\left(\text { Tvwa }_{4}\right)=\left\{\left\langle\left\{\left(\text { meat, }\left[\left[\text { mi:t } t \mathrm{AB}_{s}\right]\right)\right\},\left\{\left(\left[\text { Fleisch, }\left[{ }_{n} \mathrm{AB}_{\text {cold } \ldots . .]}\right]\right)\right\}\right\rangle,\right.\right.\right. \\
& \left\langle\left\{\left(\text { cold } \sim,\left[\text { cold } \sim \mathrm{AB}_{\text {kalter }}\right]\right)\right\},\left\{\left(\text { kalter Braten, }\left[\text { Braten } \mathrm{AB}_{\text {ass...] }}\right)\right\}\right\} .\right.
\end{aligned}
$$


The following propositions about the reference text Tvwa 4 are accordingly valid:

(meat, $\left[\left[{ }^{2}: t\right]\left[\mathrm{AB}_{s}\right]\right.$ ) is lexicographically equivalent to (Fleisch, $\left.{ }_{n} \mathrm{AB}_{\text {cold } \ldots . .]}\right]$ ).

(cold $\sim$, [cold $\sim \mathrm{AB}_{\text {kalter }}$ ) is lexicographically equivalent to (kalter Braten, [Braten $\left.A B_{\text {ass... }}\right)$.

By means of the lexicographical equivalence relation $R_{\operatorname{lex}}\left(\mathrm{TVwa}_{4}\right)$ one explicitly observes:

(i) how a case of semantic-pragmatic word equivalence, and

(ii) how a case of equivalence of syntagmas which are specific to open class expressions are textualised lexicographically in a section of a completely condensed bilingual dictionary article.

With that one also sees

(iii) how a four-place relation of the type of lexical-semantic relations which is specific for open class expressions with the cardinality of 2 , and

(iv) how a four-place relation of the type of lexical-pragmatic relation with the cardinality of 2 have been textualised.

Implicitly one also learns - although only from a specific point of view - how a user-in-action infers the equivalence relationships in Tvwa 4 by means of Tvwa ${ }_{4}$, because it is clear which items, appearing as components in the 2-tuples of the elements in the domain and the range of the lexicographical equivalence relations, are addressed to which other items within the reference text. This information on the addressing relationships can also be made explicit in the notation for a lexicographical equivalence relation and also by providing all equivalence-relevant items which appear as components in a 2-tuple, with their address symbol (which has been worked out in more detail in Wiegand 2002b; cf. also below).

A formal and at the same time graphic representation of $R_{\operatorname{lex}}\left(\mathrm{Tvwa}_{4}\right)$ can be given in the form of an arrow diagram (cf. Fig. 2-3).

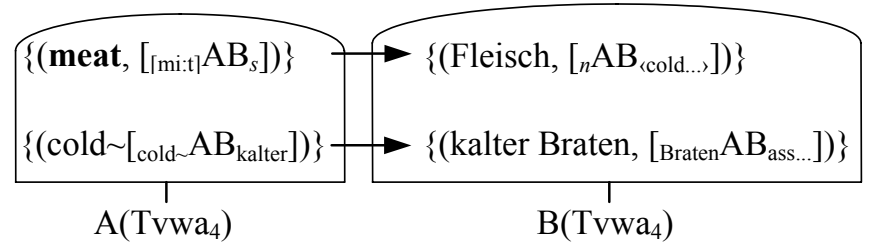

Fig. 2-3: Arrow diagram for the lexicographical equivalence relation $R_{\operatorname{lex}}\left(\operatorname{Tvwa}_{4}\right)$. 
If one defines on the set of all equivalence-relevant items of a lexicographical reference text (which is Tvwa 4 here), a two-place relation of the type of lexicographical equivalence relations, one gets the concrete lexicographical equivalence structure of the reference text. A formal representation of this structure for Tvwa 4 can be found in Fig. 2-4.

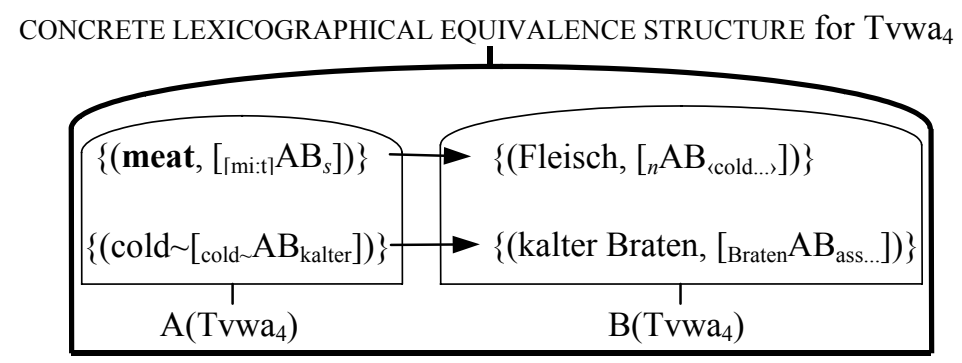

Fig. 2-4: $\quad$ Structural graph for the concrete lexicographical equivalence structure of $\mathrm{Tvwa}_{4}$

After the examples and explanations given so far, it should be clear what is meant by a specific concrete lexicographical equivalence relation. Of course, one might also like to have at one's disposal the concept of lexicographical equivalence in such a way that one could make generalisations, and not only make statements about single (excerpts from) dictionary articles. This can happen in two ways. Firstly, one could transfer from all similar concrete cases for a lexicographical equivalence relation to an abstract lexicographical equivalence relation, which represents all the concrete ones. Secondly, the generalisation can be obtained by covering all concrete cases by means of a general form for lexicographical equivalence relations. Below, an explanation is given of how both these generalisations can be obtained.

We already know the following two equivalence relations:

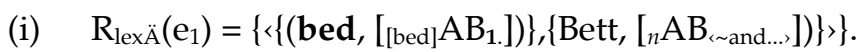

(ii) $\mathrm{R}_{\operatorname{lex} \ddot{A}}\left(\mathrm{e}_{2}\right)=\left\{\left\langle\left\{\right.\right.\right.$ meat, $\left.\left[\left[{ }_{\text {mi:tt }} \mathrm{AB}_{s}\right]\right)\right\},\left\{\left(\right.\right.$ Fleisch, $\left.\left.\left.\left.\left[{ }_{n} \mathrm{AB}_{\text {ccold... }}\right]\right)\right\}\right\rangle\right\}$.

Valid are: $R_{\operatorname{lex} \ddot{A}}\left(e_{2}\right) \subseteq R_{\operatorname{lex} \ddot{A}}\left(T v w a_{4}\right) ; R_{\operatorname{lex} \ddot{A}}\left(e_{1}\right) \subseteq R_{\operatorname{lex}}\left(T_{v w a}\right)$.

In addition, the following dictionary articles was to wa ${ }_{12}$ in Fig. 2-5 from Neubert and Gröger 1991 are given.

Was: fringe [frind3] 1. $s$ Franse $f \mid$ Saum $m$, Rand $m \mid$ Besatz $m \mid$ Ponyfrisur $f \mid$ übertr Grenze $f$, Rand(zone, -gebiet) $m(f, n)$ $\langle$ the outer $\sim \mathrm{s}$ die Randbezirke $p l\rangle \mid$ Randgruppe $f$, (besondere) Klasse $f$ the criminal $\sim$ Gruppe $f$ der Kriminellen) Zool Haarfranse $f$; 2. $v t$ mit Fransen versehen od schmücken | besetzen | einfassen 〈to $\sim$ with trees〉| um-, einzäunen; vi Fransen machen; ' ar.e.a s Rundf, Ferns 
Randbezirk $m$ (mit schlechtem Empfang); ' ben.e.fit $s$ (meist $p l$ ) Wirtsch (zusätzliche) Sozialleistung $f\langle\approx \mathrm{s}$ of a job mit einer Stelle verbundene Extras $\rangle$; fringed adj gefranst; ' $\sim$ group $s$ Randgruppe $f$; $\sim$, the-at.re $s$ Brit unkonventionelles Theater; ' $\sim$ time $s$ Ferns Randzeit $f$; 'fring.y adj fransig, Fransen-

Wa9: gawk [go:k] 1. s Tölpel $m$ Schlacks $m$; 2. vi urspr Am umg dumm glotzen od starren (at auf); ' $\sim \mathbf{y}$ 1. adj einfältig, dumm | tölpelhaft, linkisch; 2. $s$ Tölpel $m$

wa10: gem [dzem] 1. $s$ Edelstein $m \mid$ Gemme $f \mid$ übertr Prachtstück $n$, Perle $f \mid A m$ Brötchen $n$; 2. $v t$ ('gemmed, 'gemmed) mit Edelsteinen schmücken od besetzen

wa W $_{11}$ : hand.sel ['hænsl] 1. $s$ Neujahrsgeschenk $n \mid$ Handgeld $n$ | (Geschäft) erste Einnahme | übertr Vorgeschmack $m$; 2. $v t$ ein Neujahrsgeschenk machen | ein Handgeld geben | einweihen | zum ersten Mal versuchen od ausprobieren

Wa12: yacht [jot] 1. $s$ Jacht $f \mid$ (Sport) Segel-, Rennboot $n$; 2. vi auf einer Jacht fahren $\mid$ (Sport) segeln; ' club $s$ Jachtklub $m$; ' ie $s$ umg Segelboots-, bes Jachtbesitzer(in) $m(f) \mid$ Segler(in) $m(f)$; ' ing $s$ Jachtsport $m$, Segelsport $m$; 3. adj Segel-; ' er, 'yachts·man ( $p l$ 'yachts-men) $s$ Jachtfahrer $m$ Sportsegler $m$; 'yachts.man.ship $s$ Jacht-, Segelkunst $f$; 'yachts,wom-an ( $p l$ 'yachts,wom.en) s Jachtfahrerin $f$ | Sportseglerin $f$

Fig. 2-5: Dictionary articles wa $\quad$ to wa 12 from Neubert and Gröger 1991

Below, a concrete partial relation of the lexicographical equivalence relation which belongs to the reference texts, is given for each of the reference texts wa 8 to $\mathrm{wa}_{12}$.

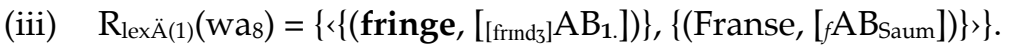

(iv) $\mathbf{R}_{\text {lex } \ddot{A}(1)}\left(\right.$ wa $\left._{9}\right)=\left\{\left\langle\left\{\left(\right.\right.\right.\right.$ gawk, $[$ [go:k $] \mathrm{AB}_{1}$. $\left.\left.]\right)\right\},\left\{\left(\right.\right.$ Tölpel, $\left.\left.\left.\left[{ }_{m} \mathrm{AB}_{\text {Schlacks }}\right]\right)\right\}\right\rangle$.

(v) $\mathrm{R}_{\text {lex } \ddot{A}(1)}\left(\mathrm{wa}_{10}\right)=\left\{\left\langle\left\{\left(\right.\right.\right.\right.$ gem, $\left.\left.\left[{ }_{\text {dzem }} \mathrm{AB}_{1}\right]\right)\right\},\left\{\left(\right.\right.$ Edelstein, $\left.\left.\left.\left[{ }_{m} \mathrm{AB}_{\mathrm{Gemme}}\right]\right)\right\rangle\right\}$.

(vi) $R_{\text {lex } \ddot{A}(1)}\left(\right.$ wa $\left._{11}\right)=\left\{<\left\{\right.\right.$ hand $\cdot$ sel, [['hænsl] $\left.\left.\left.A B_{1}\right]\right)\right\},\{($ Neujahrsgeschenk, $\left.\left.\left.\left[{ }_{n} \mathrm{AB}_{\text {Handgeld }}\right]\right)\right\}>\right\}$.

(vii) $\mathrm{R}_{\text {lex }}(1)\left(\right.$ wa $\left._{12}\right)=\left\{\left\langle\left\{\left(\right.\right.\right.\right.$ yacht, $\left[\right.$ [jot] $\left.\left.\left.\mathrm{AB}_{1 .]}\right]\right)\right\},\left\{\left(\right.\right.$ Jacht, $\left.\left.\left.\left.\left[f \mathrm{AB}_{\text {sport }}\right]\right)\right\}\right\rangle\right\}$.

The lexicographical relations (i) to (vii) are equipotent; the seven relations are, in addition, of the same kind in the following sense:

(a) As first components of all 2-tuples of all sets in the domain of the relations appear items giving the form of the lemma sign; accordingly, the 
following propositions are valid:

bed $\in$ LZGA; meat $\in$ LZGA; fringe $\in$ LZGA; gawk $\in$ LZGA;
gem $\in$ LZGA; hand sel $\in$ LZGA; yacht $\in$ LZGA.

(b) As second components of all 2-tuples of all sets in the domain of the relations appear items giving the pragmatic zero marking; accordingly, seven propositions of the same kind are valid, of which I only name the one following (i):

[[bed] $\left.\mathrm{AB}_{1 .}\right] \in \mathrm{A}$-pragNM.

(c) As first components of all 2-tuples of all sets in the range of the relations appear items giving the word equivalent; accordingly, seven propositions of the same kind are valid in this regard, of which only the one belonging to (i) is named here:

Bett $\in$ ÄA.W.

(d) As second components of all 2-tuples of all sets in the range appear items giving the pragmatic zero marking; of the seven propositions of the same kind which are valid, only the one for (i) is named:

$\left[{ }_{n} \mathrm{AB}_{\sim \sim a n d . . .}\right] \in \mathrm{A}$-pragNM.

(e) In addition, the following is valid: all 2-tuples of all sets in the domains and ranges of the relations (i)-(vii) are elements of the reference address relation, which belongs to the reference text at hand. For instance, the following propositions are valid for (iv):

(gawk, [[g:k] $\left.A B_{1 .]}\right) \in R_{\text {BeAd}}($ wa9).

(Tölpel, $\left.\left[{ }_{m} \mathrm{AB}_{\text {Schlacks }}\right]\right) \in \mathrm{R}_{\text {BeAd }}\left(\right.$ wa $\left._{9}\right)$.

Finally, the following is valid:

(f) All addressing relationships containing those items which appear at any time as equal components of a 2-tuple, are equal. Consequently, the illustration in Fig. 2-6 is valid for all examples (i) to (vii).

DOMAIN

RANGE

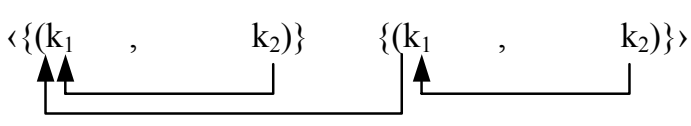

Fig. 2-6: Illustration of the addressing relationships in the reference texts (i) to (vii); Notation convention: " $\mathrm{x} \longrightarrow \mathrm{y}$ " means $x$ is addressed to $y$ 
The abstract lexicographical equivalence relation which represents the concrete relations (i) to (vii) (and many others from Neubert and Gröger 1991) can now be stated because, instead of naming items as components, one names those class symbols by means of which the classes of items with equal genuine purpose are denoted and to which the particular items belong. Accordingly, the following abstract (A) lexicographical equivalence relation (LEXÄ) belongs to the seven relations (i) to (vii):

$$
\left.\mathrm{R}_{\mathrm{ALEX}}\left(\mathrm{WA}_{1}\right)=\{((\mathrm{LZGA}, \mathrm{A}-\text { pragNM })\},\{\text { ÄA.W }, \mathrm{A}-\text { pragNM })\}\right\},
$$

in which $W_{A}$ is the set of all the involved dictionary articles appearing as reference texts, so that the following is valid: $W_{1}=\left\{w a_{4}, w a_{7}\right.$, wa $a_{8}, w a_{9}, w a_{10}$, $\left.\mathrm{wa}_{11}, \mathrm{wa}_{12}\right\}$.

In the description so far, the addressing relationships have been taken into account as prerequisites for a correct formation of the 2-tuples as the elements of the sets in the domain and the range of the lexicographical equivalence relation; however, in the formal notation of the concrete and abstract relations they have not explicitly been taken into account. This can only be changed if one expands the notation with address symbols and consequently follows the formal representation of item structures by means of structural graphs in which the reference address of the particular items in the node labelling is systematically taken into account because one adds an address symbol to each symbol of an item class by keeping to specific notation prescriptions (cf., for example, Wiegand 1990 and 1991: 103ff). Therefore, one can now state: an expression of the form $a_{i} b_{j}$ should be read as "the item $a_{i}$ with the reference address $b_{j}$ ". The expression "[[bed] $\left.A B_{1}\right] \cdot$ bed" should accordingly be read as: "the item '[[bed] $\left.A B_{1}\right]$ ' with the reference address 'bed' ". For the relation (i), this results in the following notation in which the particular address symbols were taken into account:

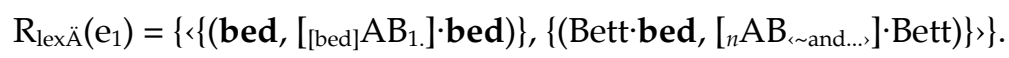

In accordance, for the relation (ii), the notation has the following form:

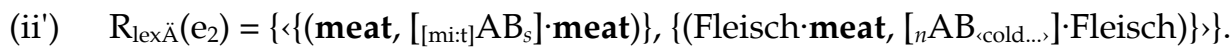

For the accompanying abstract lexicographical equivalence relation, the following notation will result accordingly:

$$
\begin{aligned}
& \mathrm{R}_{\text {ALEẌ̈ }}\left(W_{1}\right)=\{\langle\{(\text { LZGA, A-pragNM } \cdot \text { LZGA })\}, \\
& \{(\ddot{A} A . W \cdot \text { LZGA, A-pragNM } \cdot \ddot{A} A . W)\}\rangle .
\end{aligned}
$$

Next, we look at the second possibility for generalisation. In the examples so far, the following has always been the case: (i) to each source language item giving the form (in the examples it was always the item giving the form of the lemma sign), precisely one equivalence-relevant item was addressed source language-internally (in the examples it was always a A-pragNM); (ii) to the item giving the word equivalent, which is addressed to a source language item 
giving the form, precisely one equivalence-relevant item was addressed target language-internally (cf. also Fig. 2-6). In many completely condensed bilingual dictionary articles, however, not only one, but various equivalence-relevant items can be addressed to the source language item giving the form as well as to the target language item giving the form. This has as a result that not only one set appears in the domain and the range of a lexicographical equivalence relation which only exhibits one 2-tuple as element (as in all the examples so far), but also sets with $\mathrm{m}$ 2-tuple $(\mathrm{m} \geq 2 ; \mathrm{m} \in \mathrm{NI})$. Such dictionary articles are, for example, $\mathrm{wa}_{13}$ to $\mathrm{wa}_{16}$ in Fig. 2-7.

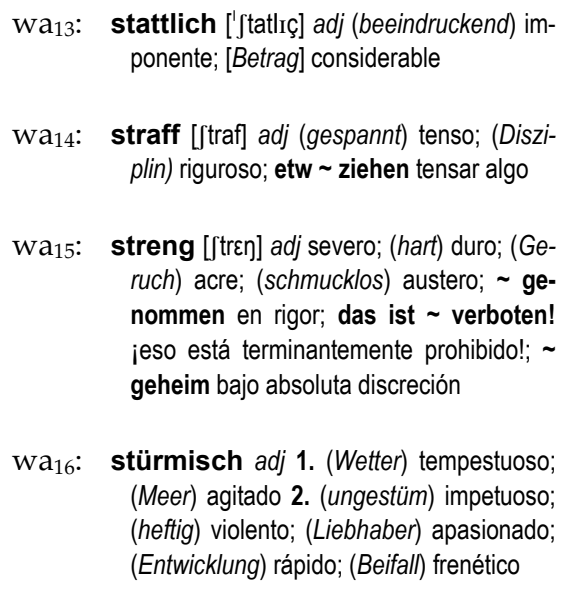

Fig. 2-7: Dictionary articles wa ${ }_{13}-{ }^{-} a_{16}$ from DE. Dt.-Span./Es.-Al. 1999

In the articles $\mathrm{wa}_{13}$ to $\mathrm{wa}_{16}$, if-then relationships given in the dictionary subject domain are textualised lexicographically as conditions for equivalence in such a way that various equivalence-relevant items are addressed to the item giving the form of the lemma sign and in most cases also to the target language items giving the equivalent. Firstly, let us look at $\mathrm{wa}_{13}$. According to the accompanying metatext of the dictionary, a zero item should be added between the item giving the word class "adj" and the item giving the synonym functioning as the item discriminating the equivalent, "beeindruckend", in the form of an item giving pragmatic zero marking (which can be named with "[adj $\left.\mathrm{AB}_{(\mathrm{be} . . .}\right]$ ", of which the textual scope is the totality of the rest of the article, so that it is addressed within its textual scope to all items giving the form with which language forms that could be pragmatically zero marked, are named. The excerpt

$$
\mathrm{e}_{4}: \operatorname{Tv} \mathrm{wa}_{13} \text { : stattlich [...] adj (beeindruckend) imponente [...] }
$$

should then, with a view to the dictionary subject domain, be read as follows: If the lexical-semantic unit STATTLICH $H_{1}$ in one of its realised German forms is used in standard language and in its habitual sense so that it means beein- 
druckend, then it is semantically-pragmatically equivalent to a standard language Spanish form which is a realisation of the lexical-semantic unit IMPONENTE and is used in its habitual sense. With a view to the dictionary form, the following statement is accordingly valid: If in the first place the item giving the pragmatic zero label (represented by "[adjj $\left.\left.\mathrm{AB}_{(\mathrm{be} . . .}\right] "\right)$ and if in the second place the item discriminating the equivalent, "beeindruckend", is addressed to the item giving the form of the lemma sign "stattlich" and, finally, in the third place the item giving the pragmatic zero marking is also addressed to the item giving the word equivalent "imponente", then "imponente" is also addressed to the item giving the form of the lemma sign. An illustration of the addressing relationships can be found in Fig. 2-8.

(THEN...)

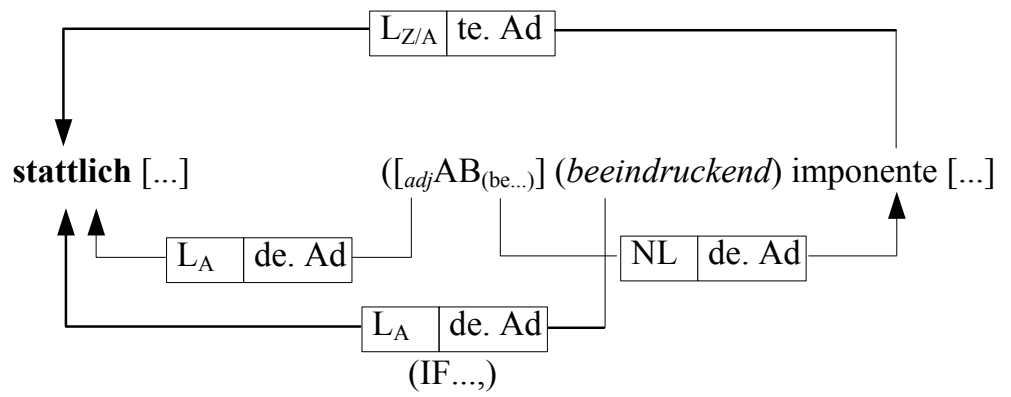

Fig. 2-8: Illustration of the addressing in $\mathrm{e}_{4} ;$ Abbreviations and notation conventions: $\mathrm{A}=$ lexicographical source language (here: German); $Z=$ lexicographical target language (here: Spanish); $\mathrm{L}_{\mathrm{Z} / \mathrm{A}}=$ addressed lemmatically from $\mathrm{Z}$ to $\mathrm{A} ; \mathrm{L}_{\mathrm{A}}=\mathrm{A}$-internally lemmatically addressed; $\mathrm{NL}=$ non-lemmatically addressed; te. $\mathrm{Ad}=$ qualified addressing; de. $\mathrm{Ad}=$ required addressing; $\mathrm{x}-\mathrm{u} \longrightarrow \mathrm{y}$ " means $x$ is article-internally $u$-addressed to $y$ with " $\mathrm{u}$ " as variable for $\mathrm{L}_{\mathrm{A}}, \mathrm{L}_{\mathrm{Z} / \mathrm{A}}$, amongst others.

In the domain (d) of the lexicographical equivalence relation to the reference text $\mathrm{e}_{4}$ now appears the following set $\mathrm{A}_{\mathrm{d}}$ of 2-tuples: $\mathrm{A}_{\mathrm{d}}=\left\{\left(\right.\right.$ stattlich, $\left.\left[{ }_{\text {adj }} \mathrm{AB}_{(\mathrm{be} . . .}\right]\right)$, (stattlich, beeindruckend) \}; in the range $(\mathrm{r})$ appears the following set: $\mathrm{B}_{\mathrm{r}}=$ $\left\{\left(\right.\right.$ imponente), $\left.\left.\left[{ }_{\text {adj }} \mathrm{AB}_{(\text {be...) }}\right]\right)\right\}$.

Accordingly, the lexicographical equivalence relation to $\mathrm{e}_{4}$ can now be stated as follows:

$$
\begin{aligned}
& \mathrm{R}_{\text {lex } \ddot{A}}\left(\mathrm{e}_{4}\right)=\left\{\left\{\left(\text { stattlich, }\left[{ }_{\text {adj }} \mathrm{AB}_{(\text {be...) }}\right],(\text { stattlich, beeindruckend })\right\},\right.\right. \\
& \left.\quad\left\{\left(\text { imponente], }\left[{ }_{\text {adj }} \mathrm{AB}_{(\text {be...) }}\right]\right)\right\}\right\} .
\end{aligned}
$$

Next, we look at the entry:

es: Tvwa ${ }_{13}:$ stattlich [...] (Betrag) considerable [...]

Firstly, it should be taken into account that the item giving the word equivalent 
"considerable" also lies within the textual scope of "[adj $\left.\mathrm{AB}_{(\mathrm{be} . . .)}\right]$ ". Accordingly, the addressing relationships in $\mathrm{e}_{5}$ are formed analogous to $\mathrm{e}_{4}$, as they are illustrated in Fig. 2-9.

(THEN...)

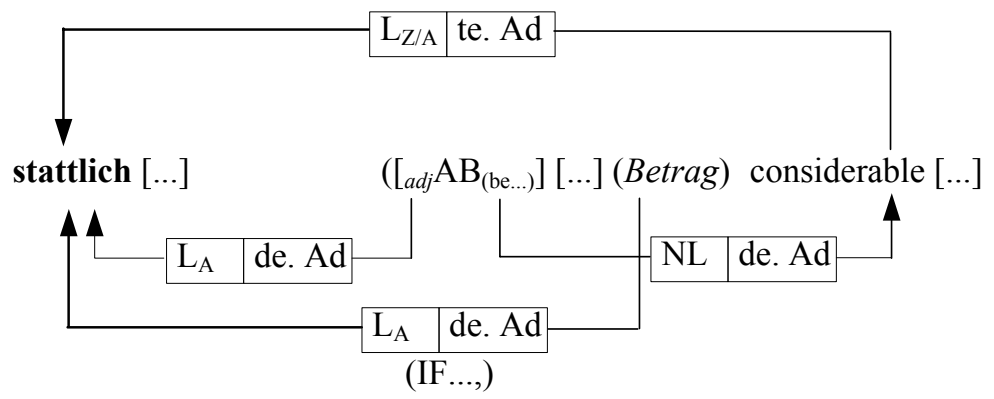

Fig. 2-9: Illustration of the addressing in $\mathrm{e}_{5}$; Abbreviations and notation conventions: as in Fig. 2-8.

The lexicographical equivalence relation for $\mathrm{e}_{5}$ thus has the following form:

$\mathrm{R}_{\text {lex }}\left(\mathrm{e}_{5}\right)=\left\{\left\langle\left\{\left(\right.\right.\right.\right.$ stattlich, $\left.\left[{ }_{\text {adjj }} \mathrm{AB}_{(\mathrm{be} . . .)}\right]\right),($ stattlich, Betrag $\left.)\right\}$,

$\left\{\left(\right.\right.$ considerable, $\left[\right.$ adj $\left.\left.\left.\mathrm{AB}_{(\mathrm{be} . . .)}\right]\right)\right\}>$.

Because $e_{4}$ and $e_{5}$ are parts of $\mathrm{wa}_{13}$, the following subset relationships are valid:

$$
\mathrm{R}_{\operatorname{lex} \ddot{A}}\left(\mathrm{e}_{4}\right) \subseteq \mathrm{R}_{\operatorname{lex} \ddot{A}}\left(w \mathrm{a}_{13}\right) ; \mathrm{R}_{\operatorname{lex} \ddot{A}}\left(\mathrm{e}_{5}\right) \subseteq \mathrm{R}_{\operatorname{lex} \ddot{A}}\left(w \mathrm{w}_{13}\right) .
$$

The lexicographical equivalence relation $R_{\operatorname{lex} \ddot{A}}\left(w_{a_{13}}\right)$ to the reference text $w a_{13}$ can be stated (extensionally complete) as follows:

$$
\begin{aligned}
& \mathrm{R}_{\operatorname{lex} \ddot{A}}\left(\text { wa }_{13}\right)\left\{\left\{\left\{\left(\text { stattlich, }\left[\text { adj }_{j} \mathrm{AB}_{(\text {be.... }}\right]\right)\right.\right.\right. \text {, (stattlich, beeindruckend)\}, } \\
& \left.\left\{\left(\text { imponente, }\left[{ }_{\text {adj }} \mathrm{AB}_{(\text {be...) }}\right]\right)\right\}\right\rangle,\left\langle\left\{\left(\text { stattlich, }\left[{ }_{\text {adj }} \mathrm{AB}_{(\text {be... }}\right]\right) \text {, (stattlich, Betrag }\right)\right\} \text {, } \\
& \left.\left.\left\{\left(\text { considerable, }\left[{ }_{\text {adj }} \mathrm{AB}_{(\text {be... }}\right]\right)\right\}\right\rangle\right\} \text {. }
\end{aligned}
$$

Fig. 2-10 shows an arrow diagram for $R_{\operatorname{lex} \ddot{A}}\left(w a_{13}\right)$ :

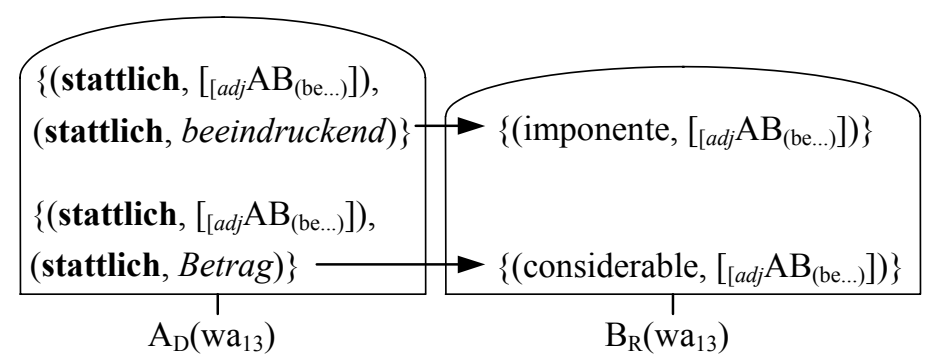

Fig. 2-10: Arrow diagram for the lexicographical equivalence relation $\mathrm{R}_{\operatorname{lex}} \mathrm{A}\left(\mathrm{w} \mathrm{a}_{13}\right)$ 
It is clear that sets which present themselves as elements $\mathrm{n}$ 2-tuples (with $\mathrm{n} \geq 2$; $\mathrm{n} \in \mathrm{NI}$ ) can also appear in the range of a lexicographical equivalence relation. The discussion of a similar example should be left out for reasons of space.

The abstract lexicographical equivalence relation which belongs to $R_{\text {lex }}\left(w_{13}\right)$ can now be stated as follows:

$$
\begin{aligned}
& \mathrm{R}_{\mathrm{ALEXÄ}}\left(\mathrm{WA}_{13}\right)=\{\{\{(\mathrm{LZGA}, \mathrm{A}-\operatorname{pragNM}),(\mathrm{LZGA}, \mathrm{ÄUnt} \mathrm{A})\} \text {, } \\
& \{(\text { ÄA.W, A-pragNM })\})>,\{(\text { LZGA, A-pragNM })\},(\text { LZGA, ÄUntA })\}, \\
& \{(\ddot{A} A . W, \text { A-pragNM })\}\}_{\text {wa }_{13}} \text {. }
\end{aligned}
$$

If one wants to follow through the process right to the end to get to the general form of a lexicographical equivalence relation, the last step can be carried out in different ways. In the following procedure a partial analogy is given for the treatment of $\mathrm{e}_{4}$ and $\mathrm{e}_{5}$, because this makes it more understandable. One proceeds from the fact that, in every completely condensed bilingual dictionary article, a set of equivalence-relevant items appears, and in addition, that these items belong to classes of equivalence-relevant items; the set could be named as $\mathrm{M}_{\text {ÄrelA }}$. This set can be divided into four disjunct subsets (where specific subsets could be empty). The following subsets are involved:

- $\quad \ddot{A} A$, the class of all target language items giving the equivalent,

- BeAd, the class of all source language items giving the form which are reference addresses of target language items giving the equivalent,

- $\quad$ ÄrelA.ÄA, the class of all equivalence-relevant items which are addressed to target language items giving the equivalent,

- $\quad$ ÄrelA. BeAd, the class of all equivalence-relevant items addressed to the source language items giving the form which are the reference addresses of the target language items giving the equivalent.

Accordingly, the following propositions are valid:

$$
\begin{aligned}
& \ddot{A} A \subseteq \mathrm{M}_{\ddot{A ̈ r e l A}} ; \mathrm{BeAd} \subseteq \mathrm{M}_{\text {ÄrelA; }} \text { ÄrelA } \cdot \ddot{\mathrm{Ä}} \mathrm{A} \subseteq \mathrm{M}_{\ddot{A ̈ r e l A}} ; \\
& \text { Ärel·BeAd } \subseteq \mathrm{M}_{\text {ÄrelA. }} \text {. } \\
& \ddot{\mathrm{A} A} \cap \mathrm{BeAd}=\varnothing ; \ddot{\mathrm{A} A} \cap \text { ÄrelA } \ddot{\mathrm{Ä}} \mathrm{A}=\varnothing ; \\
& \ddot{A} \mathrm{~A} \cap \text { ÄrelA } \cdot \mathrm{BeAd}=\varnothing ; \mathrm{BeAd} \cap \text { ÄrelA } \cdot \ddot{\mathrm{A} A}=\varnothing \text {; } \\
& \mathrm{BeAd} \cap \text { ÄrelA·BeAd }=\varnothing ; \text { ÄrelA } \cdot \ddot{A} A \cap \text { ÄrelA·BeAd }=\varnothing \text {. }
\end{aligned}
$$

In the following notation, which is stated for the general form of the lexicographical equivalence relation, one should interpret expressions of the form $X^{n}$ and $Y_{m}$ as "the nth element which has been selected from $X "$ and "the mth element which has been selected from $Y$ " respectively, so that therefore, for example, BeAdi should be read as "the ith element which has been selected from the class BeAd". The general form of a lexicographical equivalence relation can then be stated as follows: 


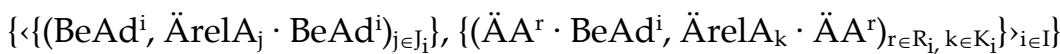

$$
\begin{aligned}
& \text { with } \mathrm{I}=\{1, \ldots, \mathrm{n}\}, \mathrm{n} \in \mathrm{IN} \\
& \mathrm{J}_{\mathrm{i}}=\subset \mathrm{IN}, \mathrm{R}_{\mathrm{i}} \subset \mathrm{IN}, \mathrm{K}_{\mathrm{i}} \subset \mathrm{IN} .
\end{aligned}
$$

Consequently, the following is valid: If $\mathrm{j}$ equivalence-relevant items (Ärel $\mathrm{A}_{\mathrm{j}}$. $\left.\mathrm{BeAd}^{\mathrm{i}}\right)$ are addressed to the ith reference address $\left(\mathrm{BeAd}^{\mathrm{i}}\right)_{\mathrm{j}}$ and if equivalencerelevant items ( $\ddot{\mathrm{Arel}} \mathrm{A}_{\mathrm{k}} \cdot \ddot{\mathrm{A}} \mathrm{A}^{\mathrm{r}}$ ) are addressed to the rth item giving the equivalent $\left(\ddot{\mathrm{A}} \mathrm{A}^{\mathrm{r}}\right)_{\mathrm{k}}$ and if in addition the rth item giving the equivalent is addressed to the ith reference address $\left(\ddot{\mathrm{A}} \mathrm{A}^{\mathrm{r}} \cdot \mathrm{BeAd}{ }^{\mathrm{i}}\right)_{j}$, then the rth item giving the equivalent is lexicographically equivalent to the ith reference address, whereby the number of items giving the equivalent depends on the odds of the ith reference address.

Finally, an appropriate definition is given for the stated general form of a lexicographical equivalence relation. In this definition, the term insertable nomination expression is used as generic term in such a way that all insertable expressions in source and target language sentence constructions by means of which one makes references and predications, are valid as insertable nomination expressions. The definition reads as follows:

(D 2-1: lexicographical equivalence for expressions of open classes)

A two-place relation of lexicographical equivalence exists exactly when, with regard to a bilingual condensed dictionary article, the following conditions are met:

(1) By means of the items giving the form, appearing in the source language domain of a lexicographical equivalence relation, as well as by means of the items giving the form appearing as items giving the equivalent in the target language range, insertable nomination expressions are mentioned.

(2) The target language items giving the equivalent in the range of the lexicographical relation are addressed to source language items giving the form in the domain.

(3) The addressing relationships of the items giving the equivalent in the range of the relation to the items giving the form in the domain of the relation are qualified by the fact that the source language forms mentioned by the items giving the form in the domain are realisations of a lexical-semantic unit which is semantically-pragmatically equivalent to those particular lexical-semantic units which are realisations of those forms which are mentioned by the items giving the equivalent in the range of the relation.

(4) n Equivalence-relevant items are addressed to the items giving the form in the domain of the relation as well as to the items giving the equivalent in the range of the relation (with $n \geq 1$ ), amongst which appears at least 
one pragmatic item.

(5) The reference relationship in which the items stand to their respective reference addresses, i.e. the source language items giving the form and those particular items giving the equivalent addressed to them, is qualified by the habitual usage of the source and target language forms named by the items giving the form and the equivalent, as well as by the habitual usage of all forms which are realisations of the accompanying lexical-semantic units.

(6) The function of the pragmatic language items addressed to the source language items giving the form has to be equal to the function of the pragmatic items addressed to the item giving the equivalent.

\section{Brief view on the possibilities of optimising the practice of lexico-} graphical description in the area of equivalent open class expressions

Especially in more comprehensive bilingual dictionaries of the widely-used languages of the civilized world, there are thousands of completely condensed dictionary articles which are considerably more extensive than the longest article examples used in this discussion, namely, wa 4 and wa7, which deal with bilingual articles of medium length. Dictionary articles dealing lexicographically with dozens of equivalence relationships are not unusual, but occur all the time. One should, in fact, not suspect in principle that practicing lexicographers do not at least master the practice that they have acquired at their particular dictionary project. There are, however, enough clear indications that the particular practice has not been thought through consistently. At any rate, it has, in my opinion, not been completely understood from a theoretical point of view. I do not think that one can expect an optimisation of similar practice-based results for the description of equivalence relations which stem from practice itself. Because of the specific conditions in dictionary offices, practitioners are - that is demonstrated by the entire history of lexicography - not in a position fundamentally to reform their own practice on their own.

The optimisation of the lexicographical description of equivalent open class expressions has two different aspects, which have to be distinguished absolutely and examined separately. The first aspect deals with the subject and subject domain of the dictionary. In the last decade, the possibilities for optimisation have considerably increased in this aspect because of the steadily improving investigation possibilities in electronic corpora and because of the rapid development of corpus linguistics. This article does not deal with this aspect. An optimisation of the existing lexicographical description of equivalence relationships which relates to the dictionary form and consequently especially to the lexicographical textualisation of equivalence relationships in completely condensed bilingual dictionary articles as well as to the explanation of the textualisation in the accompanying metatexts, cannot be determined in the 
recent general bilingual dictionaries, but is urgently needed for the sake of users. The concept of lexicographical equivalence presented in this contribution and also in Wiegand (2002b), with different emphasis and further aspects, constitute in my opinion a firm basis for a far-reaching optimisation of the presentation of equivalents and the accompanying user-friendly explanations. In this way, different types of equivalence structures which belong to the article and the correlating distinct types of bilingual dictionaries can be distinguished (cf. Wiegand 2002c and 2003). Only when the textual features of different types of bilingual dictionary articles are better known, will one be successful in obtaining a well-established, purposeful and systematically teachable optimisation of the lexicographical description of equivalent open class expressions. In completely condensed bilingual dictionary articles, the relation of the article form and the article contents is very complex. Because a user can only manage to get to the article contents via the article form, it is worthwhile to investigate the form, and in future to fashion it more adequately.

\section{Notes}

1. For the distinction between text condensation and text compression as two different possibilities to condense a text, cf. Wiegand 1998a: 31f; on the perception of the text form, cf. Wiegand 1999. On micro-architectures, cf. for example, Wiegand 2001: 191ff.

2. The abbreviations which are used further on are class symbols for items with identical general genuine purpose, so that one could, for example, write Bett $\in$ ÄA.W.

3. For the expression habitual usage, cf. Wiegand 1996.

4. The fact that a set of which the element is a 2-tuple, and not the 2-tuple itself, appears in the domain of the relation, cannot be motivated sufficiently by means of example $\mathrm{e}_{1}$. It could easily make sense if one understood that an item giving the form of the lemma sign such as "bed" could be addressed to various equivalence-relevant items, so that a set of various 2tuples appear in the domain; with that the equivalence relation to $e_{1}$ becomes recognizable as a special case, because the set in the domain (and also in the range) only exhibits one element.

5. In order to draw attention to the status of the partial relation, I added (or omitted) the braces which stand directly in front of and behind the round brackets; because they are needed in the illustration of lexicographical equivalence relations with a cardinality of $>1$.

\section{Bibliography}

I thank Klaus-Peter Konerding for useful suggestions.

\section{Dictionaries}

DE. Dt.-Span./Es.-Al. 1999 = Diccionario Esencial. Deutsch-Spanisch/Español-Alemán. Taschenwörterbuch. 1999. Barcelona: Biblograf. 
Kinne and Strube-Edelmann $1980=$ Kinne, Michael and Birgit Strube-Edelmann. 1980. Kleines Wörterbuch des DDR-Wortschatzes. Düsseldorf: Schwann.

Lang. Twb. Port.-Dt./Dt.-Port. 2001 = Langenscheidt-Redaktion. 2001. Langenscheidt Taschenwörterbuch Portugiesisch-Deutsch/Deutsch-Portugiesisch. Completely revised edition. Berlin/ Munich/Vienna/Zürich/New York: Langenscheidt.

Müller 1999 = Müller, Martin. 1999. Goethes merkwürdige Wörter. Ein Lexikon. Darmstadt: Wissenschaftliche Buchgesellschaft.

Müller-Thurau 1983 = Müller-Thurau, Claus Peter. 1983. Laß uns mal 'ne Schnecke angraben. Sprache und Sprüche der Jugendszene. Third edition. Düsseldorf/Vienna: Econ-Verlag.

Neubert and Gröger 1991 = Neubert, Albrecht and Erika Gröger. 1991. Großes Handwörterbuch Englisch-Deutsch. Leipzig/Berlin/Munich: Langenscheidt.

Pons 2002 = Universalwörterbuch Deutsch-Bulgarisch. 2002. Stuttgart: Ernst Klett.

Schlosser 2000 = Schlosser, Horst Dieter. 2000. Lexikon der Unwörter. Gütersloh: Bertelsmann.

\section{Secondary literature}

Cruse, D. Alan. 1987. Lexical Semantics. Cambridge Textbooks in Linguistics. Cambridge/London/New York: Cambridge University Press.

Engelberg, Stefan and Lothar Lemnitzer. 2001. Lexikographie und Wörterbuchbenutzung. Tübingen: Stauffenburg.

Wiegand, Herbert Ernst. 1983. Was ist eigentlich ein Lemma? Ein Beitrag zur Theorie der lexikographischen Sprachbeschreibung. Wiegand, Herbert Ernst (Ed.). 1983. Studien zur neuhochdeutschen Lexikographie III. Germanistische Linguistik 1-4/82: 401-474. Hildesheim/New York: Georg Olms.

Wiegand, Herbert Ernst. 1990 [1991]. Printed Dictionaries and their Parts as Texts. An Overview on Recent Research as Introduction. Lexicographica 6: 1-26.

Wiegand, Herbert Ernst. 1996. Über usuelle und nichtusuelle Benennungskontexte in Alltag und Wissenschaft. Knobloch, Clemens and Burkhard Schaeder (Eds.) 1996. Nomination - fachsprachlich und gemeinsprachlich: 55-103. Opladen: Westdeutscher Verlag.

Wiegand, Herbert Ernst. 1998. Wörterbuchforschung. Untersuchungen zur Wörterbuchbenutzung, zur Theorie, Geschichte, Kritik und Automatisierung der Lexikographie. 1. Teilband. With 159 illustrations in the text. Berlin/New York: Walter de Gruyter.

Wiegand, Herbert Ernst. 1998a. Lexikographische Textverdichtung. Entwurf einer vollständigen Konzeption. Zettersten, Arne, Viggo Hjørnager Pedersen and Jens Erik Mogensen (Eds.). 1998. Symposium on Lexicography VIII. Proceedings of the Eighth International Symposium on Lexicography May 2-4, 1996, at the University of Copenhagen: 1-35. Lexicographica. Series Maior 90. Tübingen: Max Niemeyer.

Wiegand, Herbert Ernst. 1999. Artikel einsprachiger Lernerwörterbücher, Textgestaltwahrnehmung und Suchbereichsstrukturen. Plädoyer für übersichtliche Printwörterbücher im Zeitalter der Neuen Medien. Skibitzki, Bernd and Barbara Wotjak (Eds.). 1999. Linguistik und Deutsch als Fremdsprache: 259-281. Tübingen: Max Niemeyer.

Wiegand, Herbert Ernst. 2001. Sprachkontaktwörterbücher. Typen, Funktionen, Strukturen. Igla, Birgit, Pavel Petkov and Herbert Ernst Wiegand (Eds.). 2001. Theoretische und praktische Probleme der Lexikographie. 1. Internationales Kolloquium zur Wörterbuchforschung am Institut Ger- 
manicum der St. Kliment Ohridski-Universität Sofia, 7. bis 8. Juli 2000: 115- 224. Germanistische Linguistik 161-162. Hildesheim/New York: Georg Olms.

Wiegand, Herbert Ernst. 2002. Adressierung in zweisprachigen Printwörterbüchern. Wiegand, Herbert Ernst (Ed.). 2002. Studien zur zweisprachigen Lexikographie mit Deutsch VIII: 112-175. Germanistische Linguistik 166. Hildesheim/New York: Georg Olms.

Wiegand, Herbert Ernst. 2002a. Äquivalenz in zweisprachigen Printwörterbüchern. Kritik und Vorschläge. Wiegand, Herbert Ernst (Ed.). 2002. Studien zur zweisprachigen Lexikographie mit Deutsch VIII: 93-110. Germanistische Linguistik 166. Hildesheim/New York: Georg Olms. [English version: Equivalence in Bilingual Lexicography: Criticism and Suggestions. Lexikos 12: 239-255.]

Wiegand, Herbert Ernst. 2002b. Äquivalenz, Äquivalentdifferenzierung und Äquivalentpräsentation in zweisprachigen Wörterbüchern. Eine neue einheitliche Konzeption. [Paper presented at the Eleventh International Symposium on Lexicography, May 2002, at the University of Copenhagen, Copenhagen; in the press.]

Wiegand, Herbert Ernst. 2002c. Äquivalentpräsentation und Wörterbuchfunktionen in zweisprachigen Printwörterbüchern. [Paper presented at the Second International Symposium on Dictionary Research, 18 October 2002, in Sofia; to be published in the Proceedings.]

Wiegand, Herbert Ernst. 2002d. Über textuelle Strukturen der Wörterbuchartikel und Artikelnischen im de Gruyter Wörterbuch Deutsch als Fremdsprache. Zugleich ein Beitrag zur Weiterentwicklung einer Theorie der Wörterbuchform. Wiegand, Herbert Ernst (Ed.). 2002. Perspektiven der pädagogischen Lexikographie des Deutschen II. Untersuchungen anhand des de Gruyter Wörterbuch Deutsch als Fremdsprache: 497-595. Lexicographica. Series Maior 110. Tübingen: Max Niemeyer.

Wiegand, Herbert Ernst. 2003. Überlegungen zur Typologie von Wörterbuchartikeln in Printwörterbüchern. Ein Beitrag zur Theorie der Wörterbuchform. Lexicographica 19. 


\section{Abbreviations}

\begin{tabular}{|c|c|}
\hline A & $=$ source language (Ausgangssprache) \\
\hline ÄA.Synt & $\begin{array}{l}=\text { item giving the equivalent of syntagmas (Syntagmenäquivalentanga- } \\
\text { be) }\end{array}$ \\
\hline ÄA.W & $=$ item giving the word equivalent (Wortäquivalentangabe) \\
\hline $\mathrm{AB}$ & $=$ blank item (Angabeblank) \\
\hline A-pragNM & $\begin{aligned}= & \text { item giving the pragmatic zero marking (Angabe zur pragmatischen } \\
& \text { Nullmarkierung) }\end{aligned}$ \\
\hline ÄUntA & $\begin{aligned}= & \text { item giving the distinction for the equivalent (Äquivalentunterschei- } \\
& \text { dungsangabe) }\end{aligned}$ \\
\hline AusA & $=$ item giving the pronunciation (Ausspracheangabe) \\
\hline de.Ad & $=$ required addressing (bedingende Adressierung) \\
\hline $\mathrm{d}$ & $=$ domain $($ Vorbereich) \\
\hline $\mathrm{k}$ & $=$ component $($ Komponente $)$ \\
\hline LA & $\begin{aligned}= & \text { source language-internally lemmatically addressed (ausgangsspra- } \\
& \text { chenintern lemmatisch adressiert) }\end{aligned}$ \\
\hline $\operatorname{lp}$ & $\begin{aligned}= & \text { lexical-pragmatic equivalence relation (lexikalpragmatische Äquiva- } \\
& \text { lenzrelation) }\end{aligned}$ \\
\hline ls & $\begin{array}{l}=\text { lexical-semantic equivalence relation (lexikalsematische Äquivalenzre- } \\
\text { lation) }\end{array}$ \\
\hline $\mathrm{LZ} / \mathrm{A}$ & $\begin{array}{l}=\text { addressed lemmatically from } \mathrm{Z} \text { to } \mathrm{A} \text { (von } \mathrm{Z} \text { nach } \mathrm{A} \text { lemmatisch adres- } \\
\text { siert) }\end{array}$ \\
\hline LZGA & $=$ item giving the form of the lemma sign (Lemmazeichengestaltangabe) \\
\hline NL & $=$ non-lemmatically addressed (nicht lemmatisch adressiert) \\
\hline $\mathrm{r}$ & $=$ range $($ Nachbereich $)$ \\
\hline $\mathrm{R}_{\mathrm{Ad}}$ & $=$ addressing relation (Adressierungsrelation) \\
\hline $\mathrm{R}_{\mathrm{An}}$ & $=$ item relation (Angaberelation) \\
\hline$R_{\text {Bea }}$ & $=$ treatment relation (Bearbeitungsrelation) \\
\hline $\mathrm{R}_{\text {BeAd }}$ & $=$ reference addressing relation (Bezugsadressenrelation) \\
\hline$R_{\text {Erw }}$ & $=$ relation of mentioning (Erwähnungsrelation) \\
\hline $\mathrm{R}_{\operatorname{lex} \ddot{A}}$ & $\begin{aligned}= & \text { lexicographical equivalence relation (lexikographische Äquivalenzre- } \\
& \text { lation) }\end{aligned}$ \\
\hline RT & $=$ two-place relation term (zweistelliger Relationsterm) \\
\hline $\mathrm{T}$ & $=$ part, excerpt $($ Teil $)$ \\
\hline $\mathrm{TC}$ & $=$ typology criterion (Typologiekriterium) \\
\hline te.Ad & $=$ qualified addressing (bedingte Adressierung) \\
\hline $\mathrm{v}$ & $=$ of (von) \\
\hline v.KollA & $\begin{array}{l}=\begin{array}{l}\text { condensed item giving the collocation (verdichtete Kollokationsan- } \\
\text { gabe) }\end{array}\end{array}$ \\
\hline wa & $=$ dictionary article (Wörterbuchartikel) \\
\hline WAA & $=$ item giving the word class (Wortartangabe) \\
\hline WUntA & $=$ item giving the word class distinction (Wortunterscheidungsangabe) \\
\hline $\mathrm{Z}$ & $=$ target language (Zielsprache) \\
\hline
\end{tabular}

